\title{
Bone loss in Gorham's disease: A case study
}

\author{
BIN CHEN $^{1}$, XIAOFENG LV ${ }^{1}$, JINXIAO WU ${ }^{1}$, XINGGUANG ZHANG ${ }^{1}$, \\ XIUMIN JIAO $^{1}$, JING ZHAO ${ }^{1}$, QIANPENG CHENG ${ }^{1}$ and CAN CUI $^{2}$ \\ ${ }^{1}$ Department of Endocrinology and Metabolism, The Military General Hospital of Beijing PLA, Beijing 100700; \\ ${ }^{2}$ Department of Endocrinology and Metabolism, The 2nd Affiliated Hospital, \\ Harbin Medical University, Harbin 150080, P.R. China
}

Received December 13, 2012; Accepted January 23, 2013

DOI: $10.3892 /$ etm.2013.940

\begin{abstract}
In this study, a rare disease with characteristics of spontaneous osteolysis of the bone is reported. The patient was an eight-year-old male, who was admitted with shortness of breath. The absence of the right clavicle was identified by radiography. However, the change to the right clavicle was not malignant, as indicated by bone scanography. The biopsy of the right cervical rib revealed a number of vascular fibrous tissues and vessels distending and shunting together; however, no cell proliferation was observed. In addition, no acid-fast bacillia or malignant cells were detected in the sample of pleural effusion from the patient. Low hemoglobin $(93 \mathrm{~g} / \mathrm{l})$ and a slight elevation of alkaline phosphatase levels (133 U/1) were observed; however, the other laboratory examination results were normal. The follow-up investigation and radiotherapy results indicated that the osteolysis of the skull and the other portion of bone had not worsened. Although it has been reported that $>15 \%$ of patients succumb to this disease, the patient reported in the current study was in a relatively stable condition.
\end{abstract}

\section{Introduction}

Gorham's disease (Gorham-Stout syndrome) is a rare disorder characterized by progressive resorption of the whole or part of a bone (1-5). It is non-hereditary and often occurs in individuals aged $<40$ years without gender-related differences (6). The pathogenetic mechanism of Gorham's disease remains unknown. Phase I of this disease represents increased vascular concentration in the bone-displacing fibrous tissues. In phase II, only fibrous tissue is observed $(7,8)$. There is controversy with regard to the presence or absence of osteoclasts in this condition. In certain cases, osteoclastic activity is minimal or non-existent, whereas in other cases, osteoclasts are easily

Correspondence to: Professor Xiaofeng Lv, Department of Endocrinology and Metabolism, The Military General Hospital of Beijing PLA, No. 5 Nanmencang, Beijing 100700, P.R. China E-mail: xiaofenglv0013@163.com

Key words: ribs, maxillary bone, Gorham's disease, radiotherapy, prognosis identifiable (9). During the past 10 years, we have identified only 2 cases that were diagnosed as Gorham's disease. In the current study, we report one of these cases.

\section{Case report}

An eight-year-old male in West China was admitted with shortness of breath for 10 months. The patient was admitted to Department of Endocrinology and Metabolism, The Military General Hospital of Beijing PLA, Beijing, on September 13, 2010. Radiographs revealed the absence of the right clavicle, destruction of the anterior extremity of the right ribs and pleural effusion of the right side (Fig. 1A). Bone scanography indicated that the change in the right clavicle was not malignant. The biopsy of the right cervical rib revealed considerable vascular fibrous tissue with certain vessels distending and shunting together to form sinus construction (Fig. 1B), in which there was no endothelial cell proliferation. Masson's staining revealed the proliferation of collagen.

Acid-fast bacillia and malignant cells were not detected in a sample of pleural effusion; however, the Rivalta and Chyle tests were positive. Other laboratory investigation results were normal, with the exception of low hemoglobin (93 g/l) and a slight elevation of the alkaline phosphatase levels (133 U/l). In the follow-up examination there was no progress of osteolysis of the skull and the other portion of bone. Prior written and informed consent were obtained from every patient and the study was approved by the ethics review board of The Military General Hospital of Beijing PLA.

\section{Discussion}

One case of Gorham's disease was diagnosed according to the clinical manifestations, radiological images and the changes of histopathology. There was no family history of bone disease or trauma. The portions of bone loss were on the rib cage and maxillary bone.

The treatment options utilized previously consist of surgical resection and radiotherapy and mainly target the patient's symptoms $(6,10-14)$. The disparity of the radio-sensitivity of Gorham's disease-specific cells has resulted in mixed results following treatment (12-14). In patients with active osteoclasts, anti-resorptive therapy, including bisphosphonates or calcitonin, may improve the progressive osteolytic changes (15-17). 

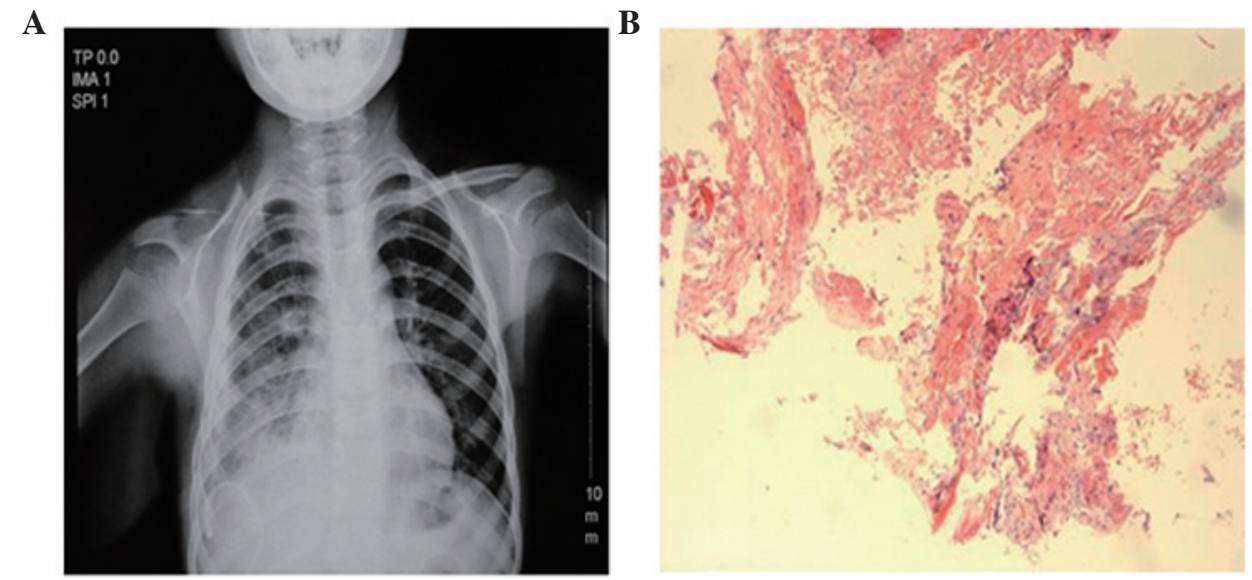

Figure 1. (A) An X-ray image of the thorax. The X-ray image revealed that the right clavicle was absent, the anterior extremities of the right ribs were destructed and pleural effusion was observed on the right side of the thorax. (B) Histological changes of the right cervical ribs. Three pieces of tissue were removed from the right cervical ribs. One was a sample of non-uniform tissue with a size of $0.8 \times 0.4 \times 0.2 \mathrm{~cm}$, while the others were two pieces of grain-like gray tissue. Proliferation of fat and fibrous connective and vascular tissue were observed under an optical microscope. Parts of vessels distended and shunted together to form a construction similar to a sinus. Hyperplastic capillaries aggregated together with monolayer flat endothelium cells coating the wall of the lumen. Proliferative collagen, a few elastic fibers and smooth muscles were observed with Masson's stain.

In the current study, radiotherapy was administered to the patient who was identified to have no osteoclasts when examined histologically. Despite the report that $>15 \%$ of patients succumb due to this disease, the patient was well with no worsening of the condition. The prognosis depends on complications, including neurological deficits and pleural effusion $(11,18)$. Life expectancy is not affected if the extremities are involved.

\section{References}

1. Gorham LW and Stout AP: Massive osteolysis (acute spontaneous absorption of bone, phantom bone, disappearing bone) its relation to hemangiomatosis. J Bone Joint Surg Am 37: 985-1044, 1955.

2. Choma ND, Biscotti CV, Bauer TW, et al: Gorham's syndrome: a case report and review of the literature. Am J Med 83: 1151-1155, 1987.

3. Jackson J: A boneless arm. Boston Med Surg J 18: 368-369, 1838.

4. Zheng MW, Yang M, Qiu JX, et al: Gorham-Stout syndrome presenting in a 5-year-old girl with a successful bisphosphonate therapeutic effect. Exp Ther Med 4: 449-451, 2012.

5. Al-Jamali J, Glaum R, Kassem A, Voss PJ, Schmelzeisen R and Schön R: Gorham-Stout syndrome of the facial bones: a review of pathogenesis and treatment modalities and report of a case with a rare cutaneous manifestations. Oral Surg Oral Med Oral Pathol Oral Radiol 114: e23-e29, 2012.

6. Hardegger F, Simpson LA and Segmueller G: The syndrome of idiopathic osteolysis. Classification, review and case report. J Bone Joint Surg Br 67: 88-93, 1985.

7. Bruch-Gerharz D, Gerharz CD, Stege H, et al: Cutaneous lymphatic malformations in disappearing bone (Gorham-Stout) disease: A novel clue to the pathogenesis to a rare syndrome. J Am Acad Dermatol 56: S21-S25, 2007.
8. Heffez L, Doku HC, Carter BL, et al: Perspectives of massive osteolysis: report of a case and review of the literature. Oral Surg Oral Med Oral Pathol 55: 331-343, 1983.

9. Dickson GR, Mollan RAB and Carr KE: Cytochemical localization of alkaline and acid phosphatase in human vanishing bone disease. Histochemistry 87: 569-572, 1987.

10. Picault C, Comtet JJ, Imbert JC, et al: Surgical repair of extensive idiopathic osteolysis of the pelvic girdle (Jackson-Gorham disease). J Bone Jt Surg Br 66: 148-149, 1984.

11. Hejgaard N and Olsen PR: Massive Gorham osteolysis of the right hemipelvis complicated by chylothorax: report of a case in a 9-year-old boy successfully treated by pleurodesis. J Pediatr Orthop 7: 96-99, 1987.

12. Fontanesi J: Radiation therapy in the treatment of Gorham disease. J Pediatr Hematol Oncol 25: 816-817, 2003.

13. Dunbar SF, Rosenberg A, Mankin H, et al: Gorham's massive osteolysis: the role of radiation therapy and a review of the literature. Int J Radiat Oncol Biol Phys 26: 491-497, 1993

14. Hanly JG, Walsh NM and Bresnihan B: Massive osteolysis in the hand and response to radiotherapy. J Rheumatol 12: 580-582, 1985.

15. Hagberg H, Lamberg K and Astrom G: Alpha-2b interferon and oral clodronate for Gorham's disease. Lancet 350: 1822-1823, 1997.

16. Hammer F, Kenn W, Wesselmann U, et al: Gorham-Stout disease - stabilization during bisphosphonate treatment. J Bone Miner Res 20: 350-353, 2005.

17. Silva S: Gorham-Stout disease affecting both hands: stabilization during biphosphonate treatment. Hand (NY) 6: 85-89, 2011.

18. Bode-Lesniewska B, von Hochstetter A, Exner GU, et al: Gorham-Stout disease of the shoulder girdle and cervico-thoracic spine: fatal course in a 65-year-old woman. Skeletal Radio 31: 724-729, 2002 